\title{
Effects of human disturbances and climate on morphological changes of Bagmati River, central Nepal
}

\author{
*Pramila Shrestha ${ }^{1}$ and Naresh Kazi Tamrakar ${ }^{2}$ \\ ${ }^{\prime}$ Department of Irrigation, Lalitpur, Nepal \\ ${ }^{2}$ Central Department of Geology, Tribhuvan University, Kathmandu, Nepal \\ (*Email:pramisht05@gmail.com)
}

\begin{abstract}
The Bagmati River of the Kathmandu basin is 7th order drainage with a length of about $51 \mathrm{~km}$ within the basin of $678 \mathrm{~km}^{2}$. This river has been suffering from haphazard urbanization and industrialization. Consequently the natural function of the river has been deteriorated. Several anthropogenic activities as channelization, sediment excavation, effluent discharge, dumping waste on and along the river bank, building roads etc. are heading the river towards a narrow and passive channel. Also, gradual changes in rainfall and river discharge trend also affecting the river morphological development. Comparative study of river morphology from 1992 and 2009 indicates that the river morphology is changing abnormally. The reduction in river discharge and stream power results from natural and anthropogenic causes has caused to increase the sinuosity of river. But stream length, belt width, meander wavelength and radius of curvature diminished. Total channel length is increased by $10 \mathrm{~km}$. This shows that the river is being deteriorated with time. Not only the mainstem Bagmati River but also its tributaries are affected from morphological impairment, and hence the river system of the Kathmandu Valley is being degraded. Thus, immediate rehabilitation (watershed management) is needed to preserve and restore natural function of river prior to the unrecoverable situation.
\end{abstract}

Keywords: Human impact, river morphology, river morphometry, Bagmati River

Received: 15 December 2010

revision accepted: 15 July 2011

\section{INTRODUCTION}

Rivers are significant geomorphological agents, which show diversity of form and behavior (Selby 1983) and have ecological and recreational values. Unwise exploitation of river resources upsets equilibrium, ecological and recreational functions of river system. The Bagmati River of the Kathmandu Valley (Fig. 1), one of the examples, suffers from unmanaged urbanization and inđustrialization, and growing population pressure on the catchment of river. Several anthropogenic activities as channelization, sediment excavation, effluent discharge, dumping waste on and along the river bank, building roads etc. have been heading the river towards a giant sewer line. Such anthropogenic activities have caused local and system scale instabilities in the Bishnumati River basin (Tamrakar 2004). Similarly, the bank recession rate of the Manahara River was recorded $0.33 \mathrm{~m} / \mathrm{yr}$ causing 1243 tons of sediment loss from banks aggravated by sediment excavation from the river (Shrestha 2007; Shrestha and Tamrakar $2007 \mathrm{a}, \mathrm{b}$ ) and the river course had shifted by $140 \mathrm{~m}$ in about 10 years (Bajracharya 2006). Besides such anthropogenic activities, gradual change in several natural phenomena in response to global climate change (suć as: changing monsoon pattern with changing intensity and amount of precipitation, fluctuation of groundwater table, reduction in discharge of natural springs etc.) are influencing the natural processes of the river. Thus the present study aims to assess the effect of human disturbances and climatic factors on the morphological changes of the Bagmati River.

\section{MATERIAL AND METHOD}

The morphometric analysis of the Bagmati basin has been conducted using geostatistical and geospatial analysis of Arc GIS software from the digital data of Department of Survey, Nepal published in year 1996. To recognize and study the effects of anthropogenic disturbances and changing climatic factors on river morphological development, morphological parameters of river corridor of two different time periods (river channel of year 1992 "based on topographic map published by the Department of Survey in 1996 prepared on the basis of aerial photo of year 1992", and year 2009 "the satellite image from Google Earth") were analyzed and studied. The measurement and analysis were performed by using Arc GIS Software. And map scale was fixed to 1:10000 for measurement and analysis. For this study river morphological parameters as- channel length (L), sinuosity $(\mathrm{K})$, meander belt width (Wblt), meander wavelength $(\mathrm{Lm})$ and radius of curvature $(\mathrm{Rc})$ were determined from river course of 1992 and 2009. And the results were verified by field observation. Furthermore, different types of anthropogenic disturbances were mapped by surveying along the river course. 


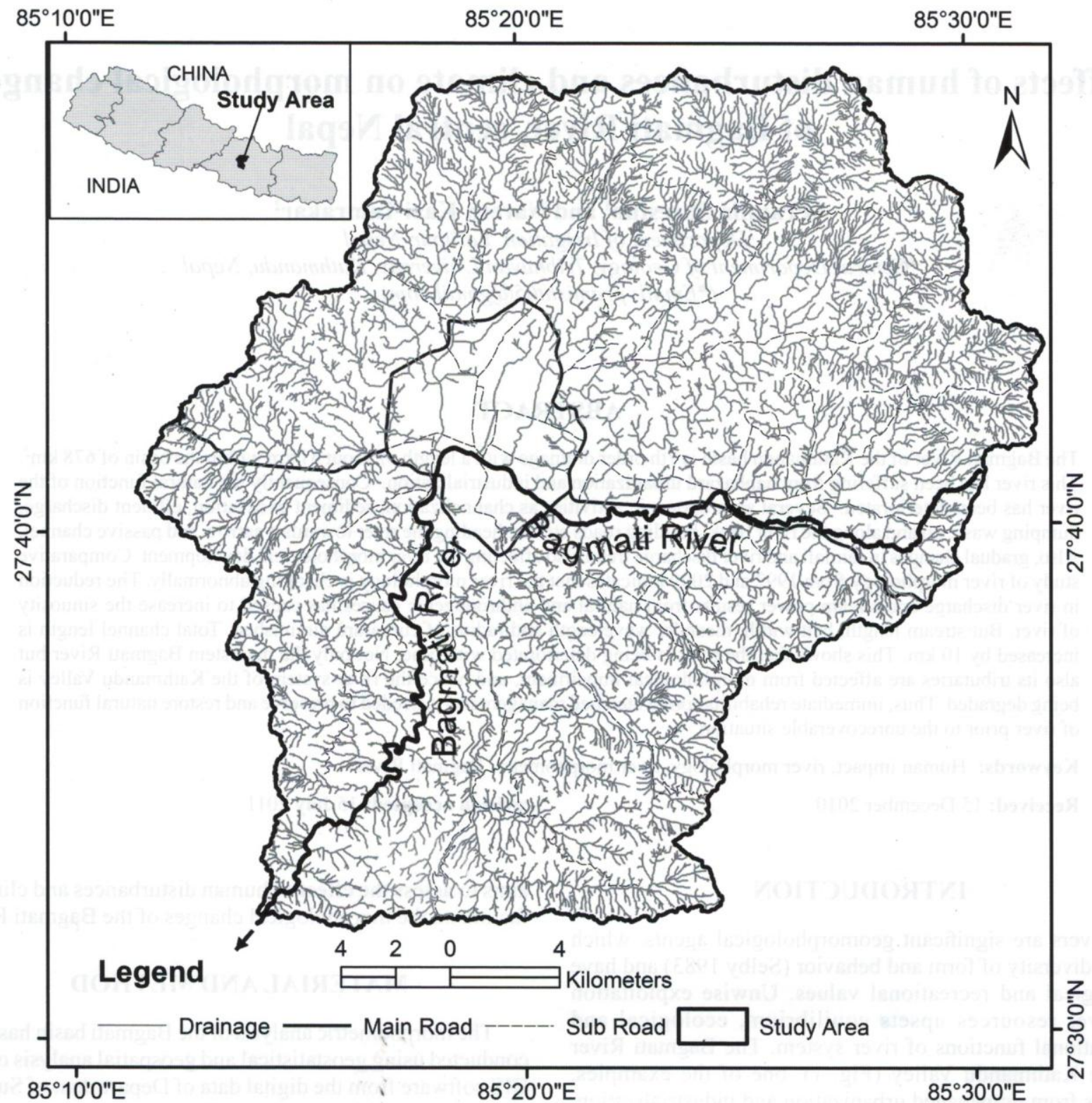

Fig. 1: Location of study area

\section{RIVER MORPHOMETRY}

The Bagmati River of the Kathmandu Valley which originates from eastern hill Nagarkot at Sudal and stretches about $51 \mathrm{~km}$ and flows over the valley covering area of $678 \mathrm{~km}^{2}$ of catchment. It is a perennial river fed by storm flows (rain fed) and springs. The geology of river basin is characterized by basin fill fluvio-lacustrine sediments (DMG 1998) underlying the basement rocks of Pre-Cambrian to Devonian ages. The basement rocks forming the surrounding hills mainly consists of phyllites, sandstones, slates, metasandstones, quartzites, siltstones, shales and crystalline limestones in the east, west and south of the valley whereas in the north and north-east site of the valley, it consists of gneiss, schist, granite etc (Stöcklin and Bhattarai 1977, Stöcklin 1980). The basement rocks forming surrounding hills of the river basin possess extremely high to high relative relief, and very fine to moderate drainage texture. Similarly, rivers which flow over the basin fill sedimentary deposits has moderate to extremely low relief, extremely coarse to coarse drainage texture (Figs. 2a and 2b).

The mainstem Bagmati River originates from eastern hill (Nagarkot) at Sudal VDC of the Kathmandu Valley within the catchment of the Hanumante River basin (Fig. 3). The Hanumante River is a 6th order drainage (according to the Strahler 1952 method of stream ordering) which stretches for $18.30 \mathrm{~km}$ and confluences with 6th order Godawori Khola 

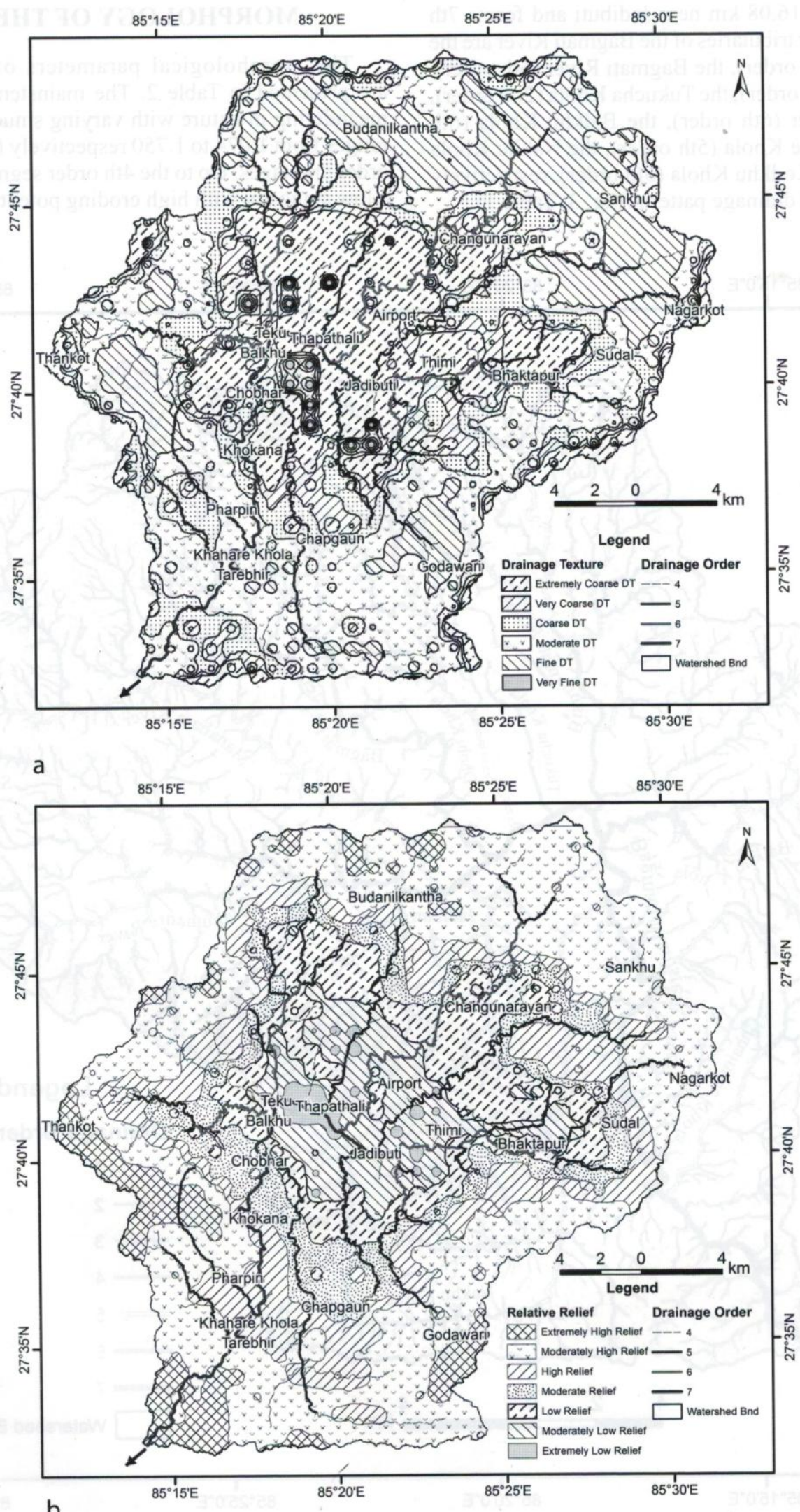

Fig. 2: Map showing (a) drainage texture (b) relative relief 
with channel length $16.08 \mathrm{~km}$ near Jadibuti and forms 7th order drainage. Major tributaries of the Bagmati River are the Manahara River (5th order), the Bagmati River (6th order), the Dhobi Khola (5th order), the Tukucha Khola (2nd order), the Bishnumati River (6th order), the Balkhu Khola (6th order), the Chhaimale Khola (5th order), the Nakhu Khola (5th order), and the Kodkhu Khola (5th order), respectively forming a centripetal drainage pattern (Fig. 3, Table 1).

\section{MORPHOLOGY OF THE RIVER}

The morphological parameters of studied segment are presented in Table 2. The mainstem Bagmati River is meandering in nature with varying sinuosity. The sinuosity ranges from 1.074 to 1.750 respectively for 1 st order and 7 th order drainages. Up to the 4th order segment, the stream has a low sinuosity with high eroding potential. The maturity of

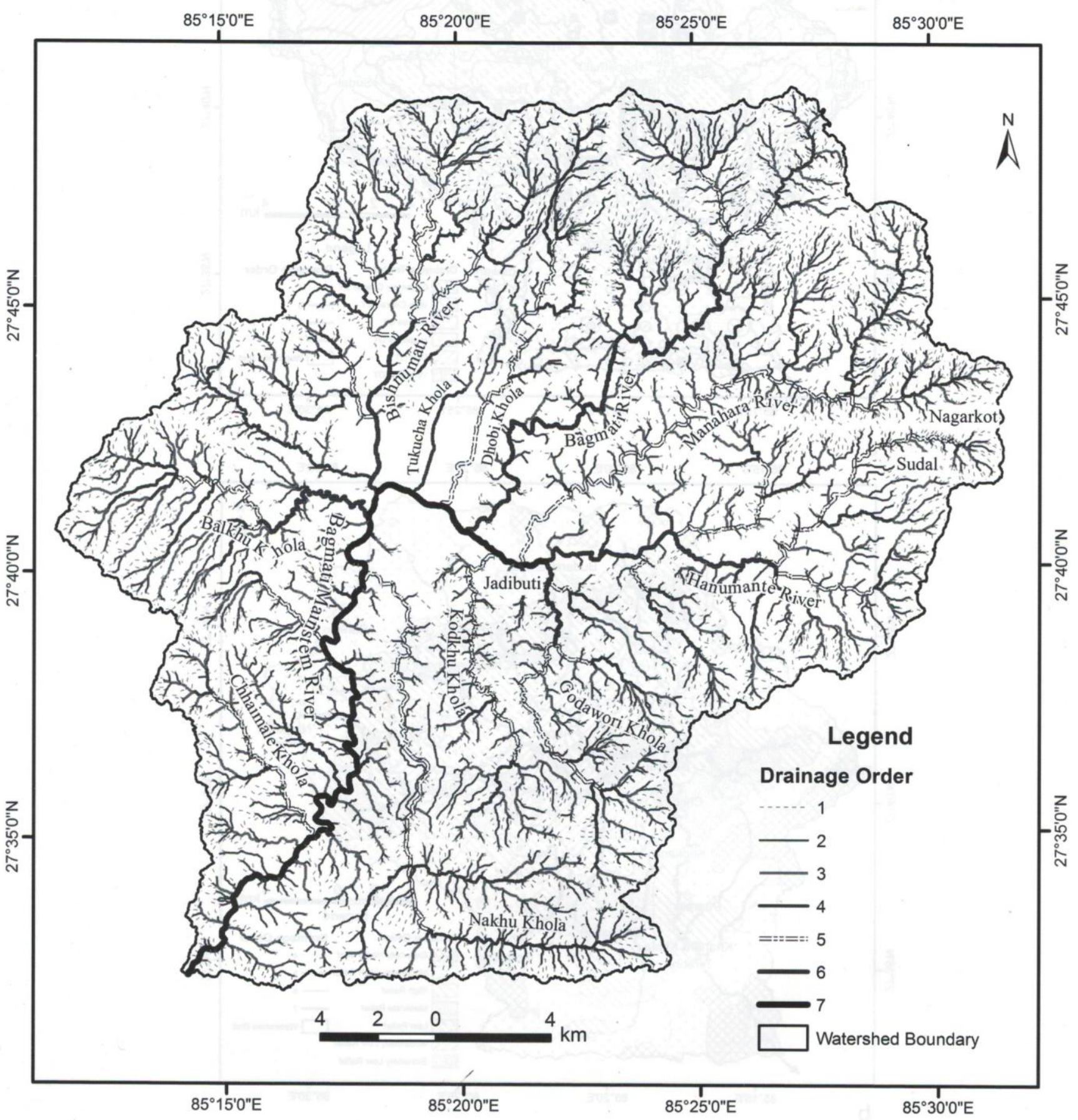

Fig. 3: Map of the Bagmati basin showing drainage order 
Table 1: Morphometric parameters of sub-watershed of the Bagmati River basin

\begin{tabular}{|l|l|c|c|c|c|c|}
\hline S.No. & Basin Name & $\begin{array}{c}\text { Drainage } \\
\text { Order }\end{array}$ & $\begin{array}{c}\text { Drainage Area } \\
(\mathrm{km})\end{array}$ & $\begin{array}{c}\text { Perimeter } \\
(\mathrm{km} 2)\end{array}$ & $\begin{array}{c}\text { Channel Length } \\
(\mathrm{km})\end{array}$ & $\begin{array}{c}\text { Basin Length } \\
(\mathrm{km})\end{array}$ \\
2 & Hanumante River & 6 & 97.05 & 53.23 & 18.30 & 16.55 \\
3 & Godavari Khola & 6 & 46.65 & 36.26 & 16.08 & 12.33 \\
4 & Manahara River & 5 & 74.26 & 62.44 & 25.24 & 19.95 \\
5 & Bagmati River & 6 & 74.13 & 61.67 & 26.94 & 20.16 \\
6 & Kodkhu Khola & 5 & 32.92 & 35.77 & 15.13 & 12.43 \\
7 & Dhobi Khola & 5 & 30.74 & 40.03 & 17.82 & 15.29 \\
8 & Tukucha Khola & 2 & 8.31 & 15.46 & 5.91 & 5.88 \\
9 & Bishnumati River & 6 & 102.26 & 57.43 & 16.34 & 16.53 \\
10 & Balkhu Khola & 6 & 43.95 & 36.01 & 16.44 & 11.35 \\
11 & Nakhu Khola & 5 & 58.72 & 64.47 & 25.59 & 22.20 \\
12 & Chhaimale Khola & 5 & 17.90 & 24.53 & 10.04 & 8.92 \\
& Bagmati Mainstem & 7 & 91.18 & 87.53 & 51.13 & 27.70 \\
\hline
\end{tabular}

stream segment increases towards downstream, and 7 th order segment is matured and meandering with a high sinuosity value indicating a potential depositional feature. The radius of curvature is the least $(61.981 \mathrm{~m})$ in 2 nd order segment and the highest $(333.336 \mathrm{~m})$ in 7 th order segment. The high value at 7 th order segment shows high degree of curvature to an individual meander bend. Similarly, the 2 nd order segment has the least value of meandering wavelength $(91.125 \mathrm{~m})$ and meander belt width $(18.113 \mathrm{~m})$, and 7 th order segment has the highest meander wavelength $(710.456 \mathrm{~m})$ and meander belt width $(202.745 \mathrm{~m})$ indicating that the 7 th order segment has a high magnitude of river wandering and lateral instability potential among all orders.

Overall river profile is concave in shape (Fig. 4). The slope between 1st and 3rd order stretch is very steep, and between 4th and 6th order is moderate. The slope from 7th order onwards is very gentle up to Katuwaldaha. The river beyond Katuwaldaha again gains steep slope. This shows that the river slope is controlled by the geology of the area. The river from 1 st to 3 rd order flows over the basement rocks of the Kathmandu Valley. The river from 4th to 7 th order with moderate to low slope flows on the unconsolidated sedimentary deposits of the Kathmandu Basin fill deposits up to the Katuwaldaha. The profile of 7 th order segment beyond Katuwaldaha after a knick point again gains steep slope and flows over the basement rocks.

\section{DISTURBANCES}

The Bagmati River basin is being disturbed from human activities as well as natural phenomenon. Thus disturbances can be resolved into anthropogenic and natural causes as briefly described below.

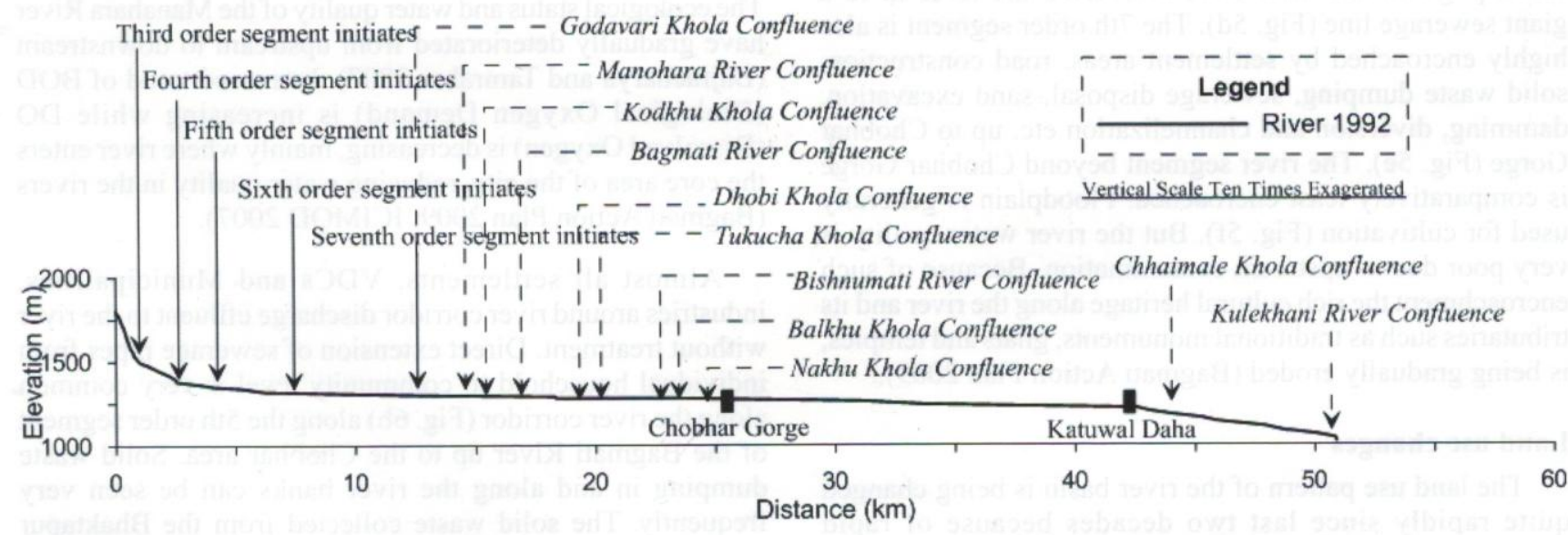

Fig. 4: Longitudinal profile of the Bagmati River 


\section{Anthropogenic disturbances}

Several anthropogenic activities related to lives and economy are factors of disturbances causing river morphological changes. The major human induced disturbances recognized along the Bagmati River are: encroachment and flood plain reduction, landuse changes, municipal and domestic effluent discharge, excavation of construction materials, channel modification, agricultural activities, etc.

\section{Urban encroachment and floodplain reduction}

Urbanization of Kathmandu Valley is one of the

Table 2: Morphological parameters of river segments from the map of year 2009

\begin{tabular}{|l|c|c|c|c|c|}
\hline Segment & $\begin{array}{c}\text { Stream Length } \\
(\mathrm{km})\end{array}$ & $\begin{array}{c}\text { Sonousity }(\mathrm{K}) \\
\mathrm{m}\end{array}$ & $\begin{array}{c}\text { Radius of Curvature } \\
(\mathrm{Rc}) ; \mathrm{m}\end{array}$ & $\begin{array}{c}\text { Meander } \\
\text { Wavelength (Lm); m }\end{array}$ & $\begin{array}{c}\text { Meander Belt } \\
\text { Width (Wblt); } \mathrm{m}\end{array}$ \\
\hline 1st order & 0.537 & 1.074 & 191.276 & 223.493 & 27.735 \\
2nd order & 0.392 & 1.137 & 61.981 & 91.125 & 18.113 \\
3rd Order & 1.878 & 1.263 & 254.951 & 432.779 & 78.366 \\
4th Order & 1.823 & 1.200 & 180.360 & 232.246 & 59.510 \\
5th Order & 4.069 & 1.189 & 248.448 & 402.835 & 84.968 \\
6th Order & 10.984 & 1.380 & 170.218 & 391.462 & 107.347 \\
7th Order & 33.805 & 1.750 & 333.336 & 710.456 & 202.745 \\
\hline
\end{tabular}

strong cause of disturbing the Bagmati River. The least encroachment is noted up to the 4 th order stream segment. Brick factories and cultivation encroach the middle and lower portion of the 5 th order stream segment (Fig. 5a). Roads constructed along both side of river banks have confined river channel and reduced channel width. Excavation of clay from the floodplain and terrace causes input of excess sediment load during monsoon flooding to the river. Newly constructed residential areas degrade the natural function of rivers. The 6 th order stretch of the river flows through the highly urban areas, and the flood plain and river banks are encroached for road construction, dumping of all types of solid wastes, disposal of effluents and chemical wastes from industrial areas, direct connection and disposal of sewerage from residential areas (Figs. $5 \mathrm{~b}, \mathrm{c}$ ). The river channel is confined by building masonry wall in both banks. Such anthropogenic activities have converted the river in to a giant sewerage line (Fig. 5d). The 7th order segment is also highly encroached by settlement areas, road construction, solid waste dumping, sewerage disposal, sand excavation, damming, diversion and channelization etc. up to Chobhar Gorge (Fig. 5e). The river segment beyond Chobhar Gorge is comparatively least encroached. Floodplain is generally used for cultivation (Fig. 5f). But the river water quality is very poor due to upstream contamination. Because of such encroachment the rich cultural heritage along the river and its tributaries such as traditional monuments, ghats and temples, is being gradually eroded (Bagmati Action Plan 2009).

\section{Land use changes}

The land use pattern of the river basin is being changed quite rapidly since last two decades because of rapid increase in population in the catchment and very high rate of urbanization and industrializations in core as well as periphery of the Kathmandu Valley. Riparian vegetation has been significantly reduced and converted to agricultural land. At present such agricultural lands have been converted to other socio-economic infrastructures (Fig. 6a).

\section{Municipal and domestic effluent discharge and solid waste dumping}

Dumping of solid waste along river banks and direct discharge of effluent and chemical waste is one of the major causes of degradation of the Bagmati River. Waste dumping activities are closely associated with clearing of riparian vegetation, reduction of floodplains and banks and channel modification, consequently contributing system instability in the river basin (Tamrakar 2004). Discharge of untreated effluent and dumping of solid waste in and along the river have also deteriorated water quality, and river environment. The ecological status and water quality of the Manahara River have gradually deteriorated from upstream to downstream (Bajracharya and Tamrakar 2007). Increased trend of BOD (Biological Oxygen Demand) is increasing while DO (Dissolved Oxygen) is decreasing, mainly where river enters the core area of the city, reducing water quality in the rivers (Bagmati Action Plan 2009; ICIMOD 2007).

Almost all settlements, VDCs and Municipalities, industries around river corridor discharge effluent to the river without treatment. Direct extension of sewerage pipes from individual household to community level is very common along the river corridor (Fig. 6b) along the 5 th order segment of the Bagmati River up to the Chobhar area. Solid waste dumping in and along the river banks can be seen very frequently. The solid waste collected from the Bhaktapur Municipality is being dumped at the banks of Hanumante River near Sallaghari. Similarly, Thimi Municipality started 


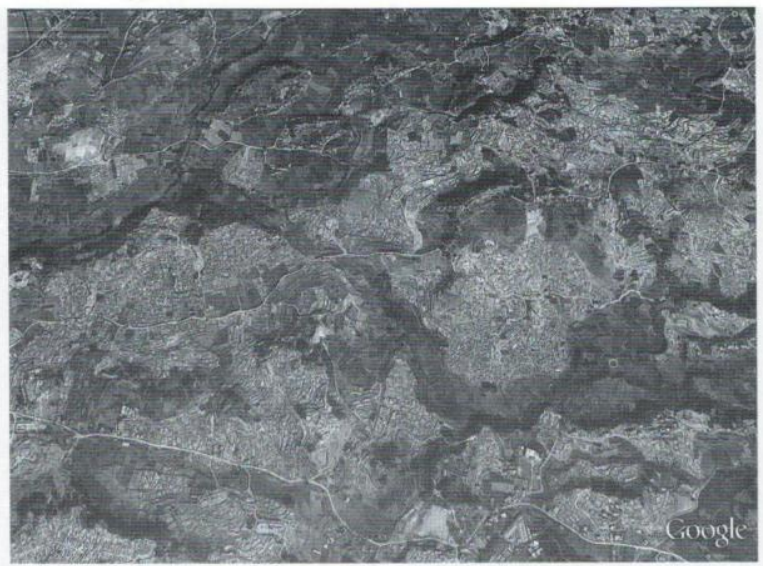

a

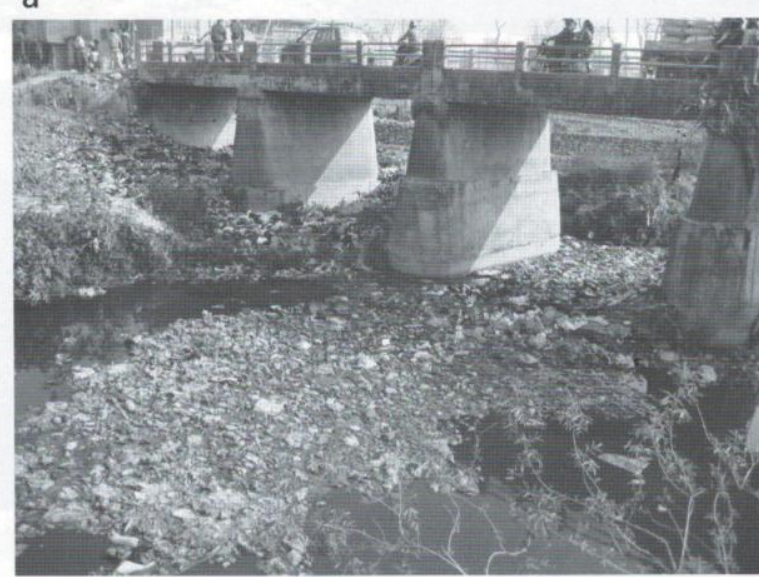

C

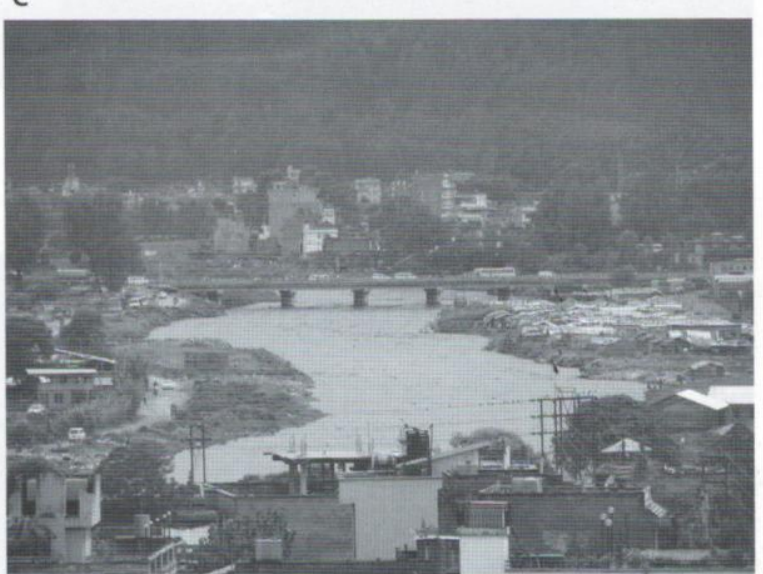

$\mathrm{e}$

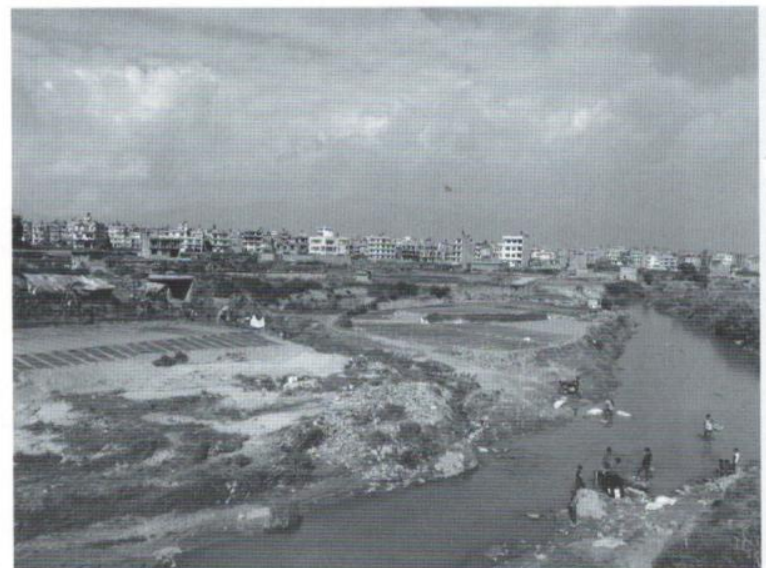

b

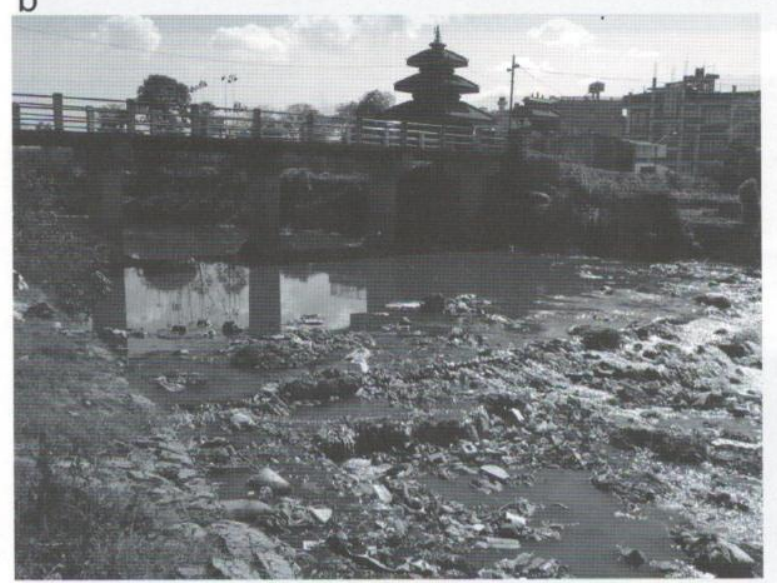

d

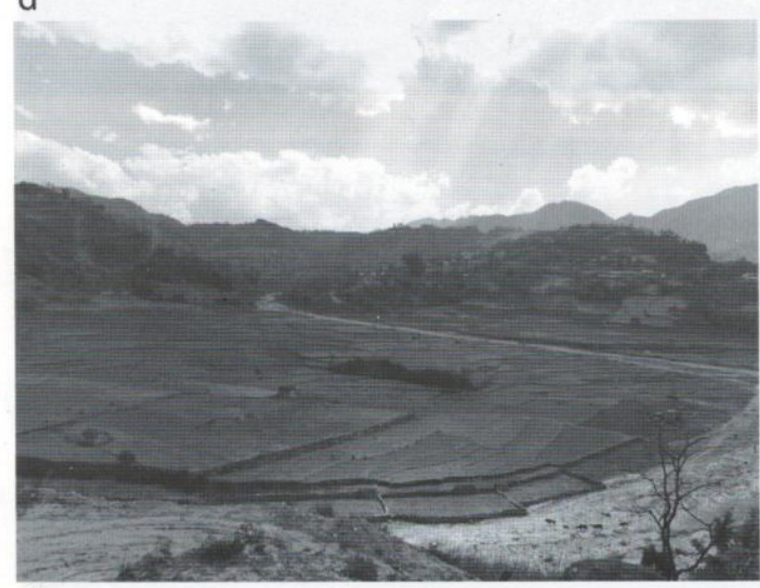

$f^{\prime}$

Fig. 5: Photographs showing (a) floodplain and bank encroachment by brick factories and cultivation at Sudal, (b) direct discharge of sewerage and effluent to river and river bar cultivation at Sano Thimi, (c) dumping of waste at river bank and channel at Thimi, (d) highly polluted river channel at Jadibuti, (e) river bank encroachment at Balkhu, and (f) cultivation on point bar at Khahare Khola near Pharping

dumping solid waste collected on the Manahara River banks at Jadibuti area. The Kathmandu Metropolitan City also dumped the solid wastes in nineties decade in both banks of the Bishnumati River extending from Balganghat to Teku, and in the banks of the Bagmati River between Teku and Chobhar (Fig. 6c). Such activities confines river channel, reduces width/depth ratio and increases channel slope; which compel the rivers morphological development deviating from natural process. And such morphological change can be observed along the river corridor within highly urban areas Bhaktapur, Thimi, Jadibuti, Thapathali, Teku, Chobhar etc. 


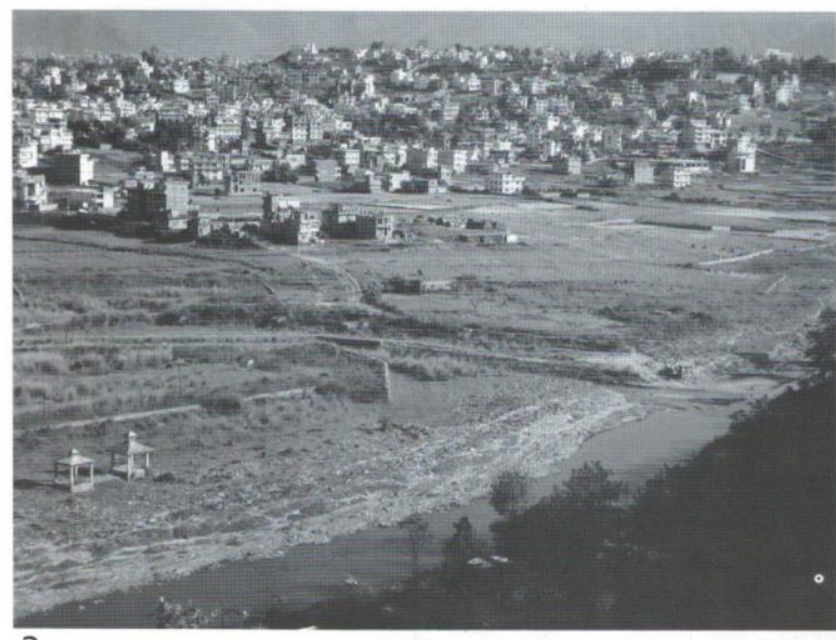

a

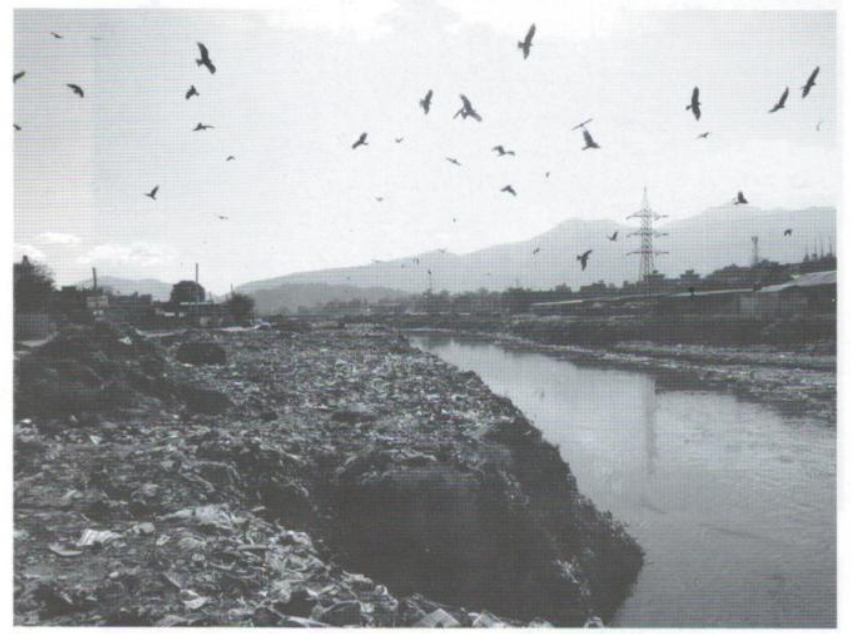

C

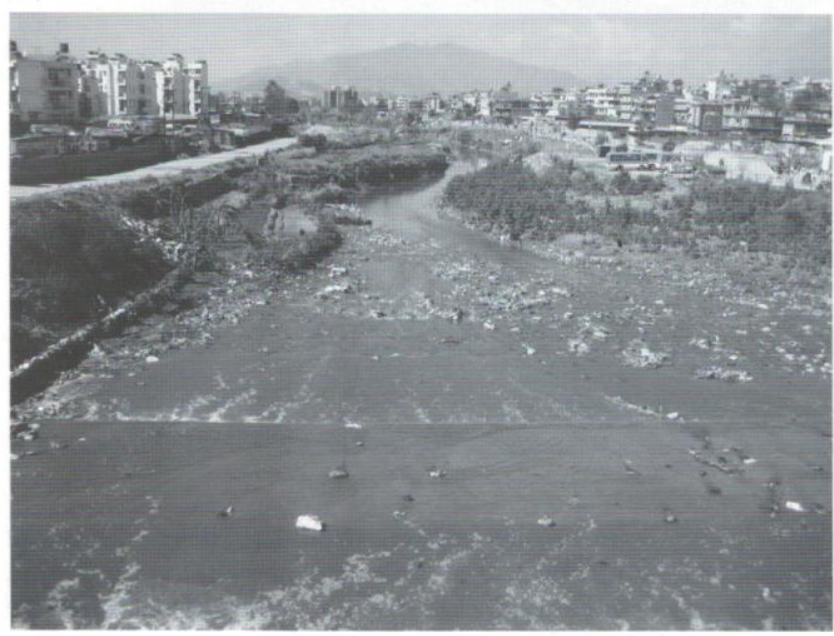

$\mathrm{e}$

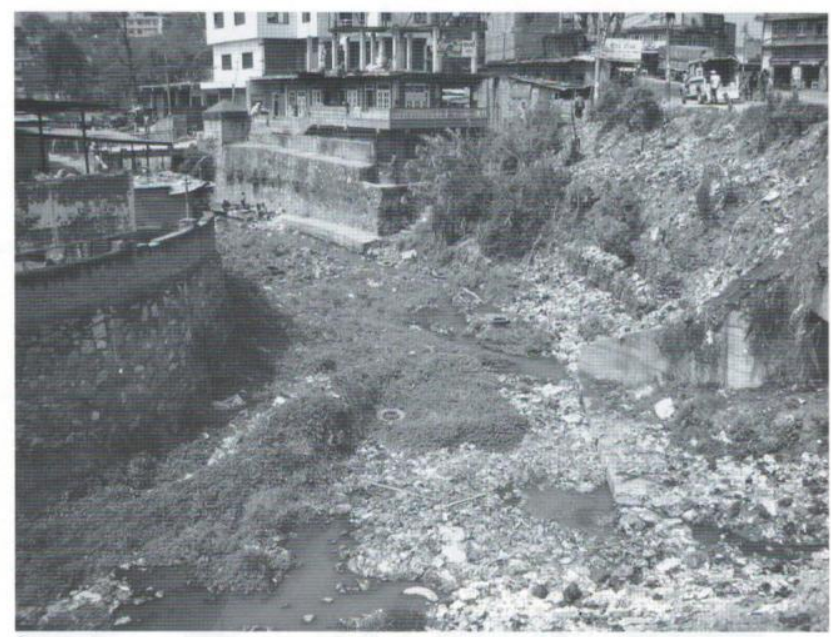

b

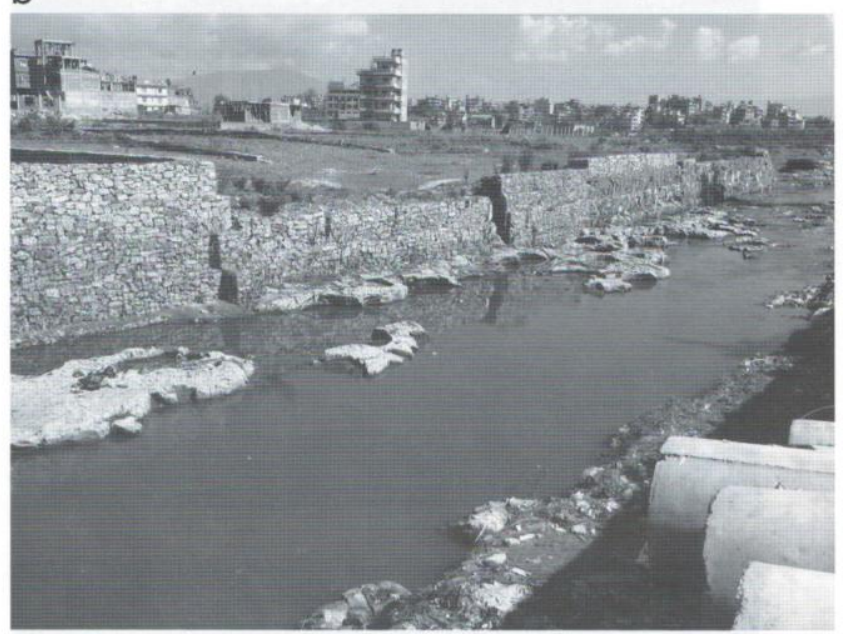

d

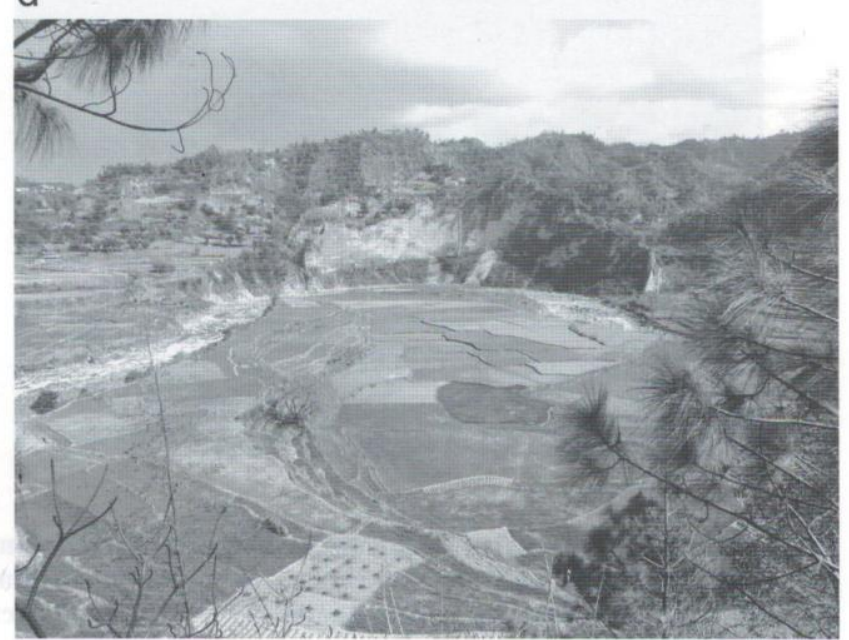

f

Fig. 6: Photographs showing (a) land use change from cultivated land to residential area near Chobhar near the confluence of Nakhu Khola and Bagmati River, (b) river bank encroachment and waste dumping on river at Balkhu (upstream view), (c) dumping of solid waste on river bank near Teku (downstream view), d) black clay layer exposed at river channel and bank encroachment near Jadibuti (upstream view), (e) confinement, channelization and encroachment of river bank at Balkumari (downstream view), and (f) cultivation on floodplain and bank at Tarebhir near Katuwal Daha 


\section{Excavation of construction material}

Numbers of brick factories are present around 4th and 5 th order segments. These brick factories are excavating clays from floodplain and terraces (Fig. 6a). Access roads are constructed along both banks where sand and gravel have been extracted. Such activities have input excess amount of sediment load to river. Increase in sediment load has increased turbidity and stream power, and facilitated river bank and bed scouring, hence exposing piers of the bridges at many locations. Sand and gravel have been extracted from river beds and banks from Jadibuti onwards. Black clay layer below sand bed, were seen exposed in most of the river beds (Fig. 6d).

\section{Narrowing and deepening of water course}

Unplanned construction of gabion structures along the bank, encroachment of river banks and excavation of huge volume of sand from the river bed are major causes of narrowing and deepening of the river bed (Fig. 6e). Originally, the Bagmati River in the urban stretch was braided and flowed over gravel and sand beds. Now, the river is confined to a single deep channel. The river bed between Teku and Thapathali is currently about 2.5 meters lower than the old bed and this has adversely affected foundations of ghats and other structures (Bagmati Action Plan 2009). Deepening of the river channel increases the flow velocity of the river that damages the infrastructures and settlements along river side. Lowering of water level in streams initiates groundwater discharge into the rivers thus lowering groundwater table in the vicinity. Structures to protect private land, schools, squatter settlements and roads along the river banks in the urban areas as Thimi, Jadibuti, Thapathali, Balkhu, Teku etc. are other reasons for river channeling (Figs. $6 \mathrm{~b}, \mathrm{~d}$ and e).

\section{Agricultural activities}

Agricultural activities are pronounced at upstream segments up to 6th order, and at 7 th order segment beyond Chobhar Gorge (Figs. 5f, 6f). People are using the river for irrigation by diversion and construction of canal, many tube wells are drilled for irrigation near river course. Such activities reduce river discharge. Excess use of fertilizer and pesticides directly and indirectly goes to river by over bank flow and contaminates river water.

\section{Natural disturbances}

Analysis of 34 years of rainfall data of the Bagmati River basin Kathmandu Valley results the annual average and the monsoon average rainfall is of $1663.73 \mathrm{~mm}$ and $334.143 \mathrm{~mm}$ respectively. The isohytal map shows highest precipitation occurring around the hills surrounding the valley (Budanilkantha), and least precipitation (900-1000 $\mathrm{mm}$ ) in core part (Khumaltar). Similarly, distribution of monsoon average precipitation (Fig. 7) is also similar to the annual precipitation.

The analysis of 34 years of average annual precipitation shows that there is gradual decreasing trend of precipitation, and total amount of rainfall received by the river basin is decreasing. Out of nine gauging stations within the river basin seven stations show decreasing trend of monthly average precipitation, one shows constant and other is slightly increasing trend (Fig. 8). In over all, general trend of monsoon precipitation within the river basin shows decreasing.

Hydrographs of average annual precipitation and average annual discharge of the watershed show that there is a positive correlation between precipitation and discharge (Fig. 9), as discharge increases with increasing precipitation. Moreover the river discharge is decreasing. Discharge in rivers governed by the amount of precipitation, and a long term trend of rainfall show decreasing trends.

Apart from reducing trend of rainfall, groundwater extraction is another cause which has been affecting flow of the Bagmati River for the last couple of years. According to Water Resources Strategy Nepal (2002) the total annual abstraction is estimated at 23.4 million cubic meter, which is much greater than the maximum recharge estimate of 14.6 million cubic meter. Also it affects on the groundwater recharge and ultimately reduces the water yield from natural springs. Since, the Bagmati River is a perennial river, fed by storm and spring flows, such changes in climatic conditions are affecting morphological development. As reduction in river discharge also reduces stream power and river starts to adjust its morphology by reducing slope and increasing sinuosity, which are obviously seen in channel changes between Thimi to Jadibuti , and Kupundol to Teku and Chobhar areas (Fig. 10).

\section{EFFECTS ON RIVER MORPHOLOGICAL CHANGE}

The morphological parameters show that there is an abnormal development in river morphology. The mainstem Bagmati River is gradually changing its morphology due to various anthropogenic disturbances. Apart from it the effect is due to reduction in required stream power (reduction in velocity and discharge), consequently the river course is wandering in its channel belt by narrowed down and confined water course, deepening the river channel, and reducing width/depth ratio.

The result of river morphological analysis shows that the sinuosity of river of all segments (from 3rd to 7 th order segment) has increased with increase in the stream length (L) during last 17 years. Whereas all other morphological parameters- radius of curvature $(\mathrm{Rc})$, wavelength $(\mathrm{Lm})$ and meander belt width (Wblt) have decreased in all the segments (Table. 3, Fig. 10). The total stream length up to 3rd order has increased by $218 \mathrm{~m}$, and average sinuosity value changed from 1.082 to 1.158 (Fig. 10 a). Similarly, stream length of 4th, 5th, 6th and 7th order segments have increased by 202 $\mathrm{m}, 153 \mathrm{~m}, 675 \mathrm{~m}$ and $973 \mathrm{~m}$ respectively. Likewise sinuosity of 4th order segment changed from 1.067 to 1.200; and 5th, 6th and 7th order segments have changed from 1.145 to $1.189,1.295$ to 1.380 and 1.731 to 1.75 respectively (Table 3, Fig. 10 b, c, d, e and f). Similarly, the values of radius 


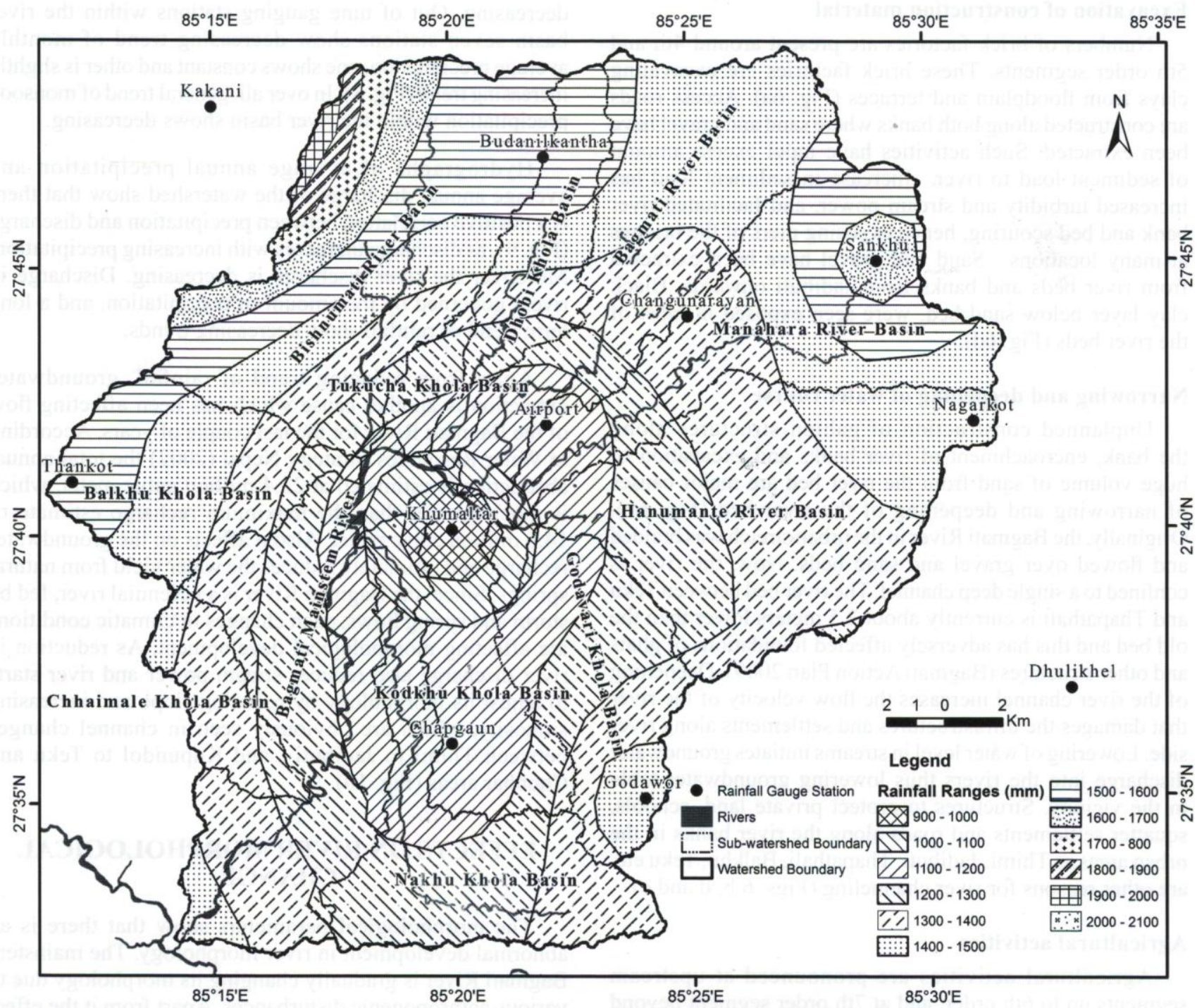

Fig. 7: Isohytal map of the average monsoon rainfall from 1975 to 2009 of the Bagmati River basin

of curvature (Rc) of the mainstem Bagmati River have decreased in all segments. Up to 3 rd order segment Rc value changed from $279.789 \mathrm{~m}$ to $169.403 \mathrm{~m}$, and 4th, 5th, 6th and 7 th order segments have changed from $381.139 \mathrm{~m}$ to 180.360 $\mathrm{m}, 261.333 \mathrm{~m}$ to $248.448 \mathrm{~m}, 462.545 \mathrm{~m}$ to $170.218 \mathrm{~m}$ and $487.906 \mathrm{~m}$ to $333.336 \mathrm{~m}$ respectively (Table 3 ). Likewise, the meander wavelength $(\mathrm{Lm})$ and meander belt width (Wblt) of third order segment has increased by $21.672 \mathrm{~m}$ and 9.841 $\mathrm{m}$; whereas rest of segments has decreased Lm by 461.240 $\mathrm{m}, 281.869,358.289 \mathrm{~m}$ and $201.292 \mathrm{~m}$ and Wblt by 29.981 $\mathrm{m}, 54.931 \mathrm{~m}, 91.036 \mathrm{~m}$ and $66.843 \mathrm{~m}$ respectively from 4 th to 7 th order segments.

Morphological changes of river channel can be observed at several places as Bhaktapur, Thimi, Jadibuti, Teku, Chobhar, Pharping, Katuwaldaha etc. with eroding banks, narrow and deep channel. This is an indication of abnormal morphological development of a river system. In a naturally developing river system when river gets more sinuous it shall adjust in the river valley by developing a wide meander belt width forming a large wavelength and radius of curvature. But in case of the Bagmati River such rule of morphological development does not satisfy. Also the longitudinal profile of river shows that the total length of the river has increased by about $10 \mathrm{~km}$ during the years 1992 to 2009 (Fig. 11), indicating increase in sinuosity and stream length. Such morphological changes are also probably caused by change in climatic factors which directly influence on rivers system as reduction of volume of rainfall and ultimately by reduction in river discharge.

Severe human encroachment in river system is the major factor causing such abnormal morphological development of the Bagmati River. Encroachment of floodplain and river banks, excavation of river bank and bed materials, disposal of solid waste and sewerage at the river etc. have entrenched and confined the river channel. At present major portion of the Bagmati River of the Kathmandu Valley has nearly lost 

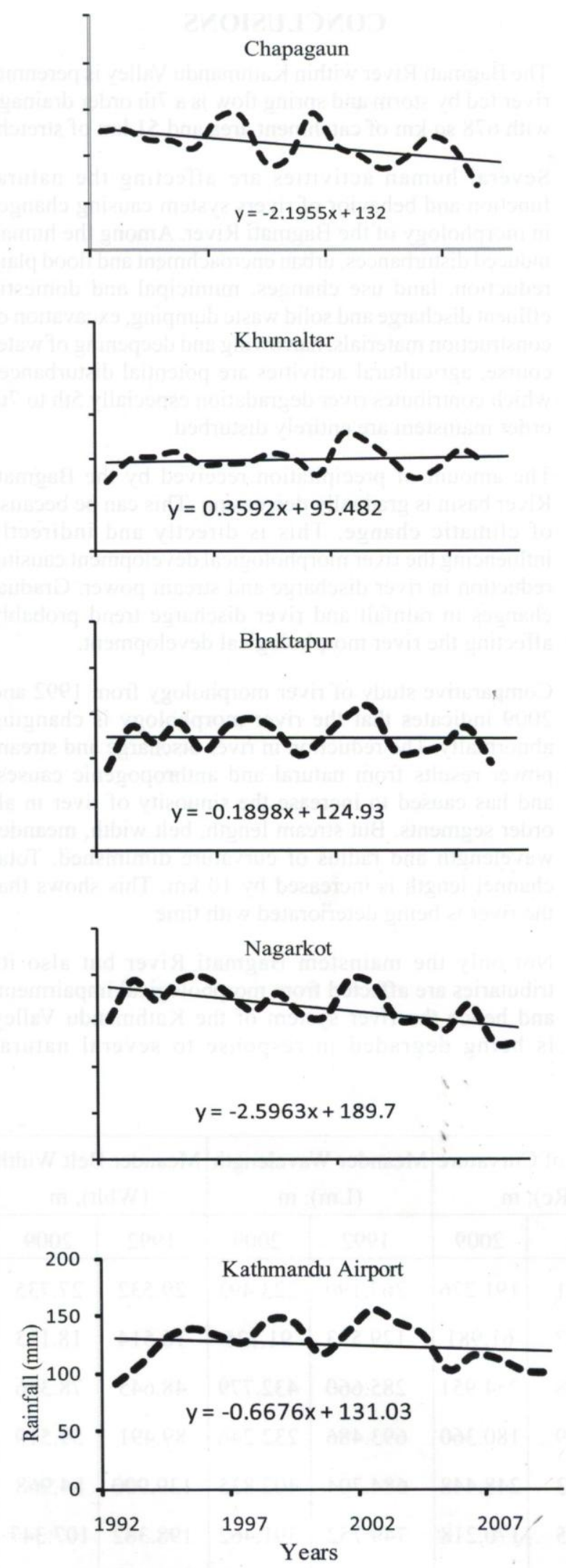
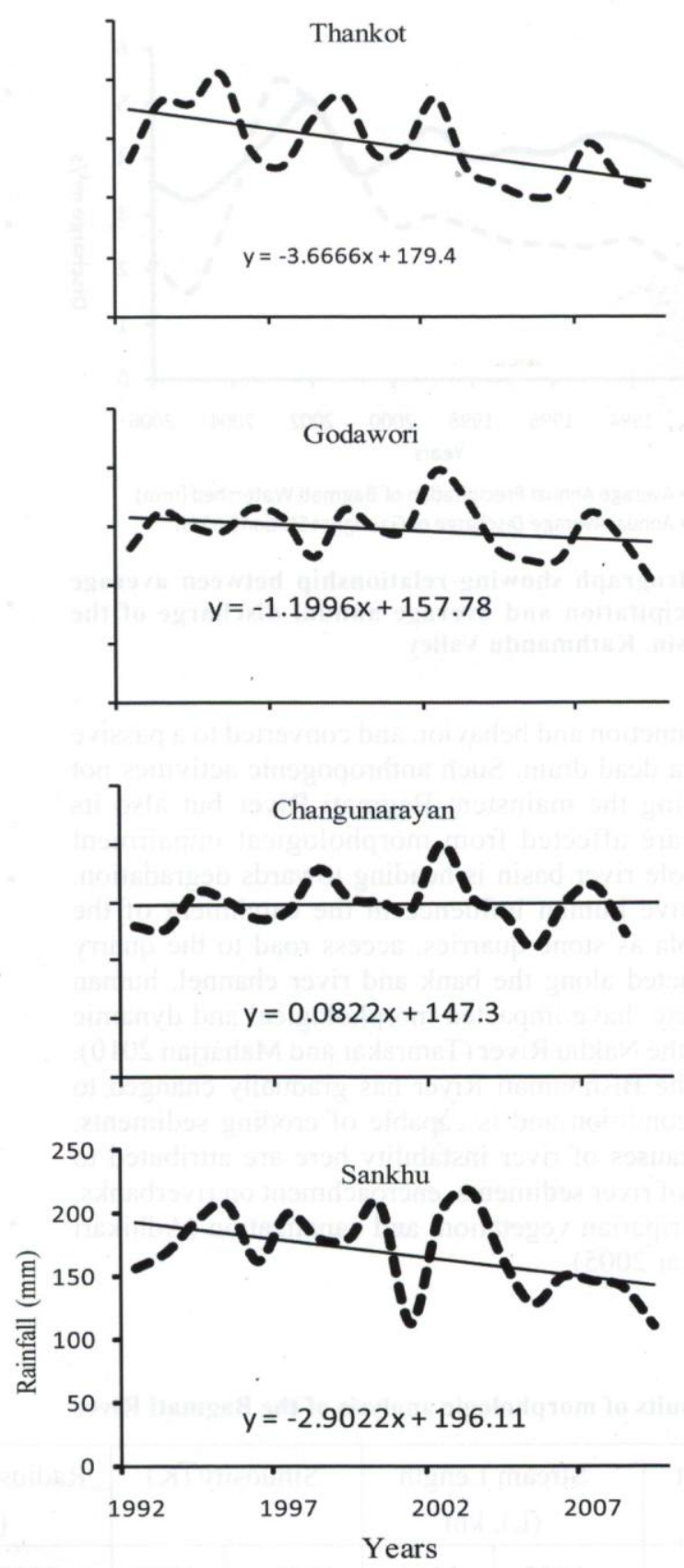

Fig. 8: Hydrograph showing average monsoon precipitation at different gauging stations 


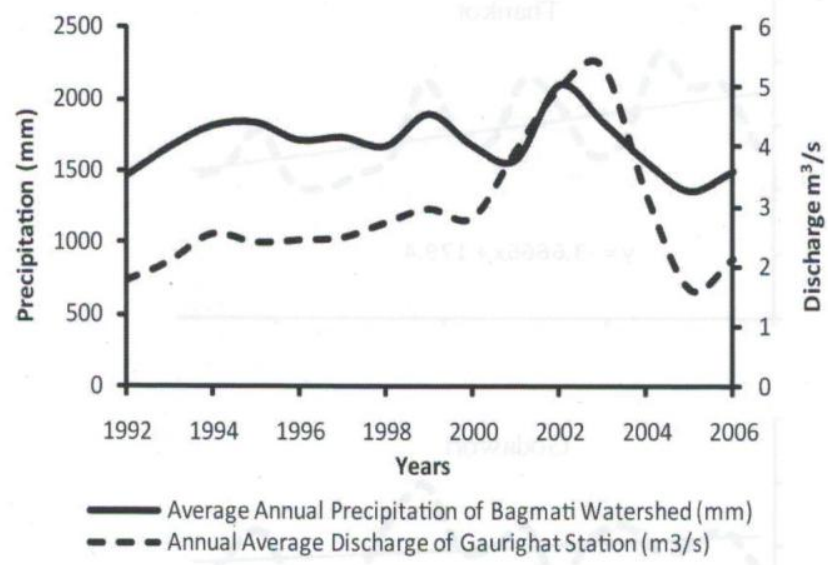

Fig. 9: Hydrograph showing relationship between average annual precipitation and average annual discharge of the Bagmati basin, Kathmandu Valley

its natural function and behavior, and converted to a passive and nearly a dead drain. Such anthropogenic activities not only affecting the mainstem Bagmati River but also its tributaries are affected from morphological impairment and the whole river basin is heading towards degradation. The excessive human influence in the catchment of the Nakhu Khola as stone quarries, access road to the quarry site constructed along the bank and river channel, human settlement etc. have impacted morphological and dynamic function of the Nakhu River (Tamrakar and Maharjan 2010). Similarly, the Bishnumati River has gradually changed to degrading condition and is capable of eroding sediments. The main causes of river instability here are attributed to excavation of river sediments, encroachment on riverbanks, clearing of riparian vegetation, and canalization (Adhikari and Tamrakar 2005).

\section{CONCLUSIONS}

- The Bagmati River within Kathmandu Valley is perennial river fed by storm and spring flow is a 7 th order drainage with $678 \mathrm{sq} \mathrm{km}$ of catchment area and $51 \mathrm{~km}$ of stretch.

- Several human activities are affecting the natural function and behavior of rivers system causing changes in morphology of the Bagmati River. Among the human induced disturbances, urban encroachment and flood plain reduction, land use changes, municipal and domestic effluent discharge and solid waste dumping, excavation of construction materials, narrowing and deepening of water course, agricultural activities are potential disturbances which contributes river degradation especially 5 th to 7 th order mainstem are entirely disturbed.

- The amount of precipitation received by the Bagmati River basin is gradually decreasing. This can be because of climatic change. This is directly and indirectly influencing the river morphological development causing reduction in river discharge and stream power. Gradual changes in rainfall and river discharge trend probably affecting the river morphological development.

- Comparative study of river morphology from 1992 and 2009 indicates that the river morphology is changing abnormally. The reduction in river discharge and stream power results from natural and anthropogenic causes, and has caused to increase the sinuosity of river in all order segments. But stream length, belt width, meander wavelength and radius of curvature diminished. Total channel length is increased by $10 \mathrm{~km}$. This shows that the river is being deteriorated with time.

- Not only the mainstem Bagmati River but also its tributaries are affected from morphological impairment, and hence the river system of the Kathmandu Valley is being degraded in response to several natural

Table 3: Results of morphologic analysis of the Bagmati River

\begin{tabular}{|c|c|c|c|c|c|c|c|c|c|c|}
\hline Segment & \multicolumn{2}{|c|}{$\begin{array}{c}\text { Stream Length } \\
(\mathrm{L}), \mathrm{km}\end{array}$} & \multicolumn{2}{|c|}{ Sinuosity (K) } & \multicolumn{2}{c|}{$\begin{array}{c}\text { Radius of Curvature } \\
(\mathrm{Rc}) ; \mathrm{m}\end{array}$} & \multicolumn{2}{c|}{$\begin{array}{c}\text { Meander Wavelength } \\
(\mathrm{Lm}) ; \mathrm{m}\end{array}$} & \multicolumn{2}{|c|}{$\begin{array}{c}\text { Meander Belt Width } \\
\text { (Wblt); } \mathrm{m}\end{array}$} \\
\hline & 1992 & 2009 & 1992 & 2009 & 1992 & 2009 & 1992 & 2009 & 1992 & 2009 \\
\hline 1st order & 0.546 & 0.537 & 1.057 & 1.074 & 179.311 & 191.276 & 267.190 & 223.493 & 29.532 & 27.735 \\
2nd order & 0.379 & 0.392 & 1.042 & 1.137 & 146.227 & 61.981 & 129.533 & 91.125 & 16.514 & 18.113 \\
3rd Order & 1.664 & 1.878 & 1.148 & 1.263 & 513.828 & 254.951 & 285.660 & 432.779 & 48.645 & 78.366 \\
4th Order & 1.621 & 1.823 & 1.067 & 1.200 & 381.139 & 180.360 & 693.486 & 232.246 & 89.491 & 59.510 \\
5th Order & 3.915 & 4.069 & 1.145 & 1.189 & 261.333 & 248.448 & 684.704 & 402.835 & 139.900 & 84.968 \\
6th Order & 10.309 & 10.984 & 1.295 & 1.380 & 462.545 & 170.218 & 749.752 & 391.462 & 198.382 & 107.347 \\
7th Order & 32.832 & 33.805 & 1.731 & 1.750 & 487.906 & 333.336 & 911.748 & 710.456 & 269.588 & 202.745 \\
\hline
\end{tabular}



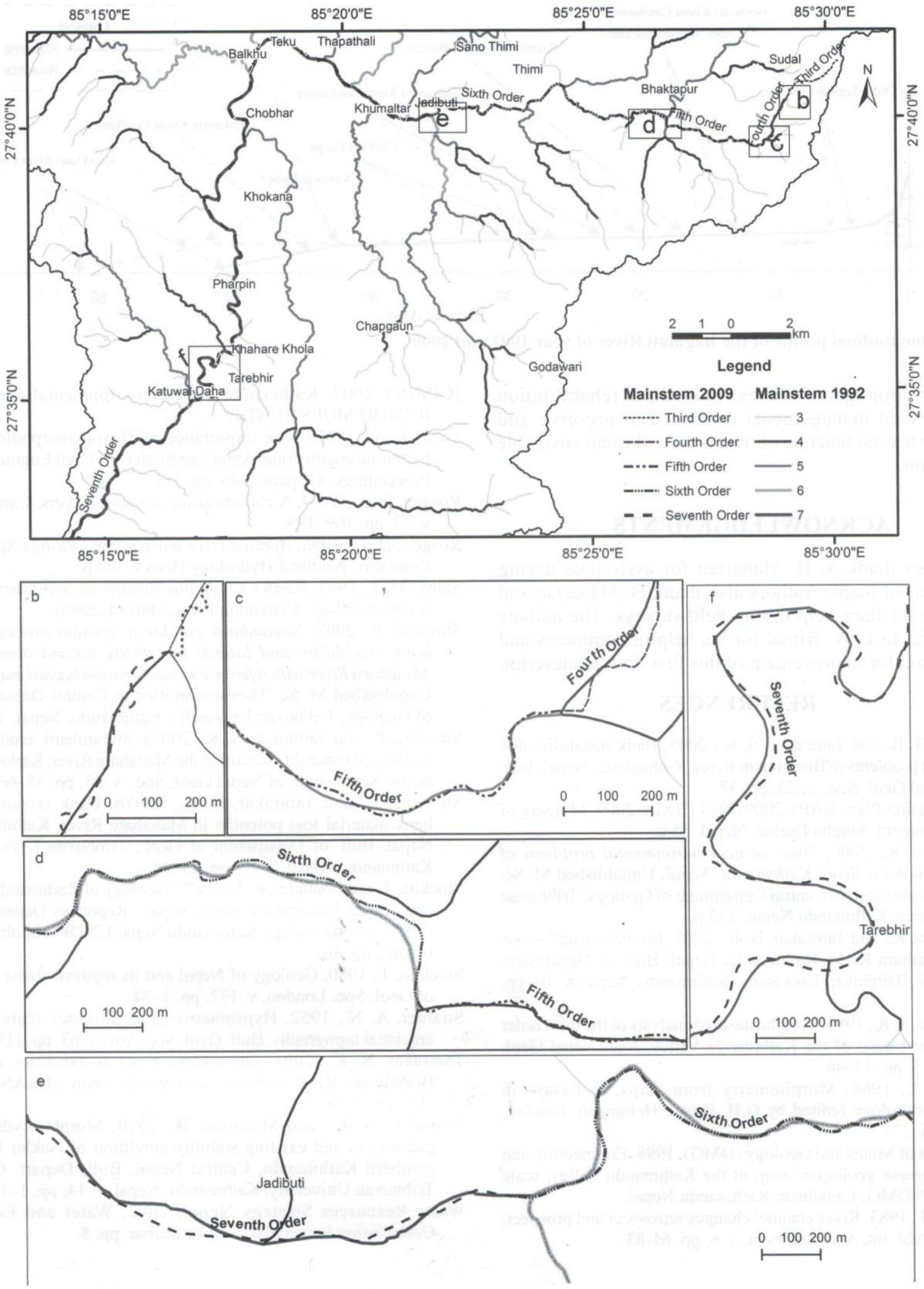

Fig. 10: Map showing morphological changes (a) the Bagmati River showing sites undergoing remarkable morphological changes; (b) third and fourth order segment, (c) fourth and fifth order segment, (d) fifth and sixth order drainage (e) sixth and seventh, and (f) portion of seventh order drainage; showing change in morphology of river channel of 1992 and 2009 


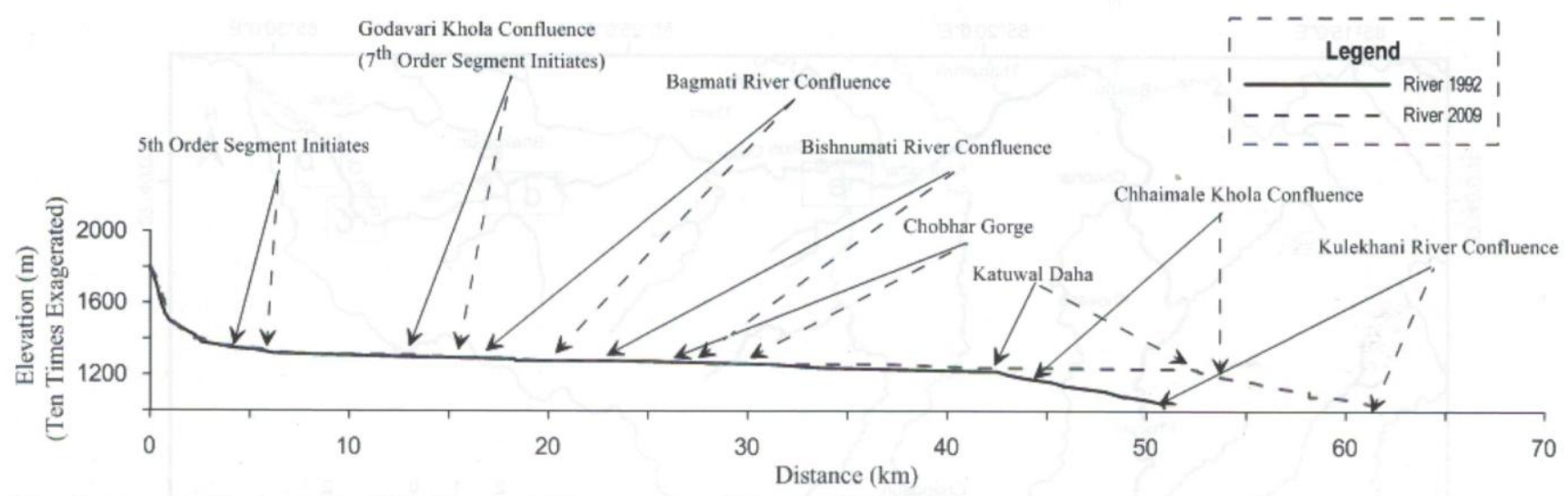

Fig. 11: Longitudinal profile of the Bagmati River of year 1992 and 2009

and anthropogenic causes. Immediate rehabilitation (watershed management) is needed to preserve and restore natural function of river prior to the unrecoverable situation.

\section{ACKNOWLEDGEMENTS}

Authors thank S. B. Maharjan for assistance during preparation of maps. Authors also thank B. Maharjan and P. Lasiwa for their help during field surveys. The authors are grateful to L. N. Rimal for his helpful comments and suggestation for improvement of this first draft manuscript.

\section{REFERENCES}

Adhikari, B. R. and Tamrakar, N. K., 2005, Bank instability and erosion problems in Bishnumati River, Kathmandu, Nepal, Jour. of Nepal Geol. Soc., v. 23, pp. 37.

Bagmati Action Plan (BAP), 2009-2014 (BAP), 2009, Ministry of Environment, Singha Darbar, Nepal, 85 p.

Bajracharya, R., 2006, Study of geoenvironmental problems of the Mahohara River, Kathmandu, Nepal. Unpublished M. Sc. Thesis submitted to Central Department of Geology, Tribhuvan University, Kathmandu Nepal, 132 p.

Bajracharya, R., and Tamrakar, N. K., 2007, Environmental status of Manahara River, Kathmandu, Nepal. Bull. of Department of Geol., Tribhuvan University, Kathmandu, Nepal, v. 10, pp. 21-32.

Bajracharya, S. R., 1996, Morphostastical analysis of the third order drainage basins of the Kathmandu Valley. Jour. Nepal Geol. Soc., v.5, pp. 37-46.

Clarke, J. I., 1966, Morphometry from maps, in Essays in Geomorphology (edited by G.H. Dury), Heinmann, London, pp. 235-274.

Department of Mines and Geology (DMG), 1998, Engineering and environment geological map of the Kathmandu Valley, scale 1:50000 DMG, Lainchaur, Kathmandu Nepal.

Hickin, E. J., 1983, River channel changes retrospect and prospect. Spec. Publ. int. Ass. Sediment, v. 6, pp. 61-83.
ICIMOD, 2007, Kathmandu Valley Environmental Outlook, ICIMOD/MOEST/UNDP.

Lane, E. W., 1955, The importance of fluvial morphology in hydraulic engineering, American Society of Civil Engineering, Proceedings, 81 , paper 745 , pp. 1-17.

Rosgen, D. L., 1994, A classification of natural rivers, Cantenna, v. 22, pp. 169-199.

Rosgen, D. L., 1996, Applied river morphology. Pasoga Springs, Colorado, Wildland Hydrology Books, 390 p.

Selby, M. J., 1983, Earth's Changing Surface, an introduction to geomorphology. Clarendon Press, Oxford, $239 \mathrm{p}$.

Shrestha, P., 2007, Streambank condition, erosion process and bank erodibility and lateral instability hazard along the Manahara River with reference to bank erosion hazard mapping. Unpublished M. Sc. Thesis submitted to Central Department of Geology, Tribhuvan University, Kathmandu, Nepal, 188 p.

Shrestha, P., and Tamrakar, N. K., 2007a, Streambank erodibility and lateral instability hazard in the Manahara River, Kathmandu basin, Nepal. Jour. of Nepal Geol. Soc., v. 35, pp. 55-66.

Shrestha, P., and Tamrakar, N. K., 2007b, Bank erosion and bank material loss potential in Manahara River, Kathmandu, Nepal. Bull. of Department of Geol., Tribhuvan University, Kathmandu, Nepal, v. 10, pp. 33-44.

Stocklin, J. and Bhattarai, K. D., 1977, Geology of Kathmandu area and central Manabharat range Nepal. Report of Department of Mines and Geology Kathmandu Nepal/UNDP (unpublished report), pp. 86.

Stocklin, J., 1980, Geology of Nepal and its regional frame. Jour. of Geol. Soc. London, v. 137, pp. 1-34.

Strahler, A. N., 1952, Hypsometric (area-altitude) analysis of erosional topography. Bull. Geol. Soc. Am., v. 63, pp. 1117-42.

Tamrakar, N. K., 2004, Disturbances and instabilities in the Bishnumati River corridor, Kathmandu basin, JUSAN, v. 9 (19), pp. 7-18.

Tamrakar, N. K., and Maharjan, B., 2010, Morpho-hydraulic parameters and existing stability condition of Nakhu River, southern Kathmandu, Central Nepal. Bull. Depart. Geol., Tribhuvan University, Kathmandu, Nepal, v. 14, pp. 1-12.

Water Resources Strategy Nepal, 2002, Water and Energy Commission Secretariat, Singha Darbar, pp. 8. 